\title{
EFFECT OF POST-POLYMERIZATION TREATMENTS ON THE FLEXURAL STRENGTH AND VICKERS HARDNESS OF RELINE AND ACRYLIC DENTURE BASE RESINS
}

\author{
Rosangela Seiko SEO ${ }^{1}$, Carlos Eduardo VERGANI ${ }^{2}$, Eunice Teresinha GIAMPAOLO ${ }^{2}$, \\ Ana Claudia PAVARINA ${ }^{3}$, Ana Lucia MACHADO ${ }^{2}$
}

\author{
1- Professor, Dental School, University of Várzea Grande, Várzea Grande, MT, Brazil. \\ 2- Associate Professor, Department of Dental Materials and Prosthodontics, Dental School of Araraquara, São Paulo State University, Araraquara, \\ SP, Brazil. \\ 3- Assistant Professor, Department of Dental Materials and Prosthodontics, Dental School of Araraquara, São Paulo State University, UNESP, \\ Araraquara, SP, Brazil. \\ Corresponding address: Dr. Carlos Eduardo Vergani - Faculdade de Odontologia de Araraquara - UNESP - Rua Humaitá nº 1680 - 14801-903 \\ - Araraquara, SP, Brasil - Phone: +55-16-3301-6410 - Fax: +55-16-3301-6406. e-mail: vergani@foar.unesp.br \\ Received: July 2, 2007 - Accepted: August 27, 2007
}

\begin{abstract}
T

Lis study evaluated the effect of water-bath and microwave post-polymerization treatments on the flexural strength and Vickers hardness of four autopolymerizing reline resins (Duraliner II-D, Kooliner-K, Tokuso Rebase Fast-TR and Ufi Gel Hard C-UGH) and one heat-polymerized acrylic resin (Lucitone 550-L), processed using two polymerization cycles (short cycle - 90 minutes at $73^{\circ} \mathrm{C}$ and $100^{\circ} \mathrm{C}$ for 30 minutes; and long cycle -9 hours at $\left.71^{\circ} \mathrm{C}\right)$. For each material, thirty specimens $(64 \times 10 \times 3.3 \mathrm{~mm})$ were made and divided into 3 groups $(n=10)$. Specimens were tested after: processing (control group); water-bath at $55^{\circ} \mathrm{C}$ for 10 minutes (reline materials) or 60 minutes (L); and microwave irradiation. Flexural strength tests were performed at a crosshead speed of $5 \mathrm{~mm} / \mathrm{min}$ using a three-point bending device with a span of $50 \mathrm{~mm}$. The flexural strengths values were calculated in $\mathrm{MPa}$. One fragment of each specimen was submitted to Vickers hardness test. Data were analyzed by 2-way ANOVA followed by Tukey's HSD test $(\alpha=0.05)$. L microwaved specimens (short cycle) exhibited significantly higher flexural strength means than its respective control group $(\mathrm{p}<0.05)$. Water-bath promoted a significant increase $(\mathrm{p}<0.05)$ in flexural strength of $\mathrm{K}$ and $\mathrm{L}$ (long cycle). The hardness of the tested materials was not influenced by the post-polymerization treatments. Post-polymerization treatments could be used to improve the flexural strength of some materials tested.
\end{abstract}

Uniterms: Microwaves; Acrylic resins; Denture liners; Hardness.

\section{INTRODUCTION}

An optimal adaptation of the denture bases to its supporting structures is closely related to the retention of the denture and health and preservation of the underlying tissues. However, residual ridge reduces over an indefinite period of time and these gradual changes of oral tissues require that complete or partial dentures be relined to improve their adaptation to the supporting tissues ${ }^{7,15}$.

Autopolymerizing reline resins offer an immediate and relatively simple means to directly recondition the denture base surface of ill-fitting prostheses? ${ }^{7}$. Despite these advantages, several autopolymerizing reline resins present lower flexural strength than heat-polymerized acrylic resins ${ }^{2,23,29}$ and the flexural strength of heat-polymerized acrylic resins can be significantly decreased after relining ${ }^{2,21,23}$. This is due to the fact that there is higher residual monomer in autopolymerizing acrylic resins than in heat-polymerized acrylic resins ${ }^{13,27,28}$. The reason for the higher residual monomer content in the autopolymerizing acrylic resin is the low degree of conversion achieved by the use of a chemical activator as opposed to that generated by heat activation ${ }^{26}$. As a result, not all monomer is converted into polymer in autopolymerizing acrylic resins ${ }^{22}$. This residual monomer acts as a plasticizer, thus resulting in deleterious effect on the mechanical properties of denture base resins $^{5,13}$. In addition, residual monomer resulting from incomplete conversion of monomers into polymer has the potential to elicit irritation, inflammation and an allergic response by oral mucosa ${ }^{4}$.

In order to overcome these limitations, several techniques to increase the degree of conversion of autopolymerizing acrylic resins and thus reduce the residual monomer content have been advocated, such as immersion in hot water ${ }^{11 ; 16,24,25}$ and microwave irradiation ${ }^{5,16,25,29,30}$. However, there are no reports in the literature comparing the influence of these two postpolymerization treatments on the physicomechanical properties 
of acrylic resins.

The aim of this study was to determine the effect of waterbath and microwave post-polymerization treatments on the flexural strength and Vickers hardness of four different autopolymerizing reline resins and one heat-polymerized acrylic resin. The hypothesis tested was that the flexural strength and Vickers hardness of the reline and acrylic denture base resins would be improved by the post-polymerization treatments.

\section{MATERIALAND METHODS}

Four autopolymerizing reline resins were selected for comparison to a conventional heat-polymerized acrylic resin (Table 1). Tokuso Rebase Fast and Ufi Gel Hard C contain high percentages of cross-linking agent. The liquid composition of Kooliner is isobutyl methacrylate, without a cross-linking agent, whereas Duraliner II liquid contains butyl methacrylate and a cross-linking agent. Lucitone 550 heat-polymerized acrylic resin was selected as representative of the poly(methyl methacrylate) heat-polymerized acrylic resins, which are commonly used for the fabrication of denture bases.

Each material was mixed according to the manufacturer's instructions and applied to a stainless steel mold ( 64 x 10 x 3.3 $\mathrm{mm}$ ) placed on an acetate sheet and a glass slab. A second acetate sheet and glass slab was placed over the material and light pressure was applied to expel excess material from the mold. For Ufi Gel Hard C, the material was applied with an automixing syringe. All autopolymerizing specimens were allowed to polymerize undisturbed. The sides of all specimens were ground with 400-grit silicon carbide paper (3M, St. Paul, MN, USA) to remove irregularities. The accuracy of the dimensions (width and thickness) was verified with a micrometer (Mitutoyo Sul Americana, Suzano, SP, Brazil), accurate to $0.01 \mathrm{~mm}$, at 3 locations of each dimension to within $0.02 \mathrm{~mm}$ tolerance ${ }^{8}$. The final specimen dimensions were $64 \mathrm{~mm}$ length, $10 \pm 0.02 \mathrm{~mm}$ width and $3.3 \pm 0.02 \mathrm{~mm}$ height ${ }^{8}$.

To fabricate Lucitone 550 specimens, initially, silicone impression material (Optosyl Confort, Heraeus Kulzer, Dormagen, Germany) was adapted inside the stainless steel mold. The silicone patterns were invested by sandwiching them between 2 glass slides in type IV stone (Vel-Mix, Kerr, Romulus, MI, USA), using a conventional denture processing flask (Bethil Ind e Co Ltda, Marília, SP, Brazil). Lucitone 550 material was mixed, packed under pressure and processed according to the manufacturer's recommendations (Table 1). Considering

TABLE 1- Materials used in this study

\begin{tabular}{|c|c|c|c|c|c|c|c|c|}
\hline \multirow[t]{2}{*}{ Product } & \multirow[t]{2}{*}{ Manufacturer } & \multirow[t]{2}{*}{ Type } & \multirow{2}{*}{$\begin{array}{c}\text { Powder } \\
\text { liquid } \\
\text { ratio }\end{array}$} & \multirow{2}{*}{$\begin{array}{l}\text { Polymerization } \\
\text { condition }\end{array}$} & \multicolumn{2}{|c|}{ Composition } & \multicolumn{2}{|c|}{ Batch number } \\
\hline & & & & & Powder & Liquid & Powder & Liquid \\
\hline Duraliner II & $\begin{array}{l}\text { Reliance Dental } \\
\text { Mfg. Co., Place } \\
\text { Worth, IL., USA }\end{array}$ & $\begin{array}{l}\text { Autopolymerizing } \\
\text { acrylic resin }\end{array}$ & $\begin{array}{l}2.0 \mathrm{~g} \\
2 \mathrm{~mL}\end{array}$ & $\begin{array}{l}12 \text { min at room } \\
\text { temperature }\end{array}$ & PEMA & BMA & 031501 & 012201 \\
\hline Kooliner & $\begin{array}{l}\text { GC America Inc, } \\
\text { Alsip, IIL, USA }\end{array}$ & $\begin{array}{l}\text { Autopolymerizing } \\
\text { acrylic resin }\end{array}$ & $\begin{array}{l}2.1 \mathrm{~g} \\
1.5 \mathrm{~mL}\end{array}$ & $\begin{array}{l}10 \text { min at room } \\
\text { temperature }\end{array}$ & PEMA & IBMA & 080700 & 062900A \\
\hline $\begin{array}{l}\text { Ufi Gel Hard } \\
\text { C }\end{array}$ & $\begin{array}{l}\text { Voco, Cuxhaven, } \\
\text { Germany }\end{array}$ & $\begin{array}{l}\text { Autopolymerizing } \\
\text { acrylic resin }\end{array}$ & $\begin{array}{l}\text { A u t o - } \\
\text { mixing }\end{array}$ & $\begin{array}{l}7 \text { min at room } \\
\text { temperature }\end{array}$ & PEMA & 1,6-HDMA & & 05 \\
\hline $\begin{array}{l}\text { Tok u s o } \\
\text { R e b a s e } \\
\text { Fast }\end{array}$ & $\begin{array}{l}\text { Tokuyama Dental } \\
\text { Corp, Tsukuba, } \\
\text { Japan }\end{array}$ & $\begin{array}{l}\text { Autopolymerizing } \\
\text { acrylic resin }\end{array}$ & $\begin{array}{l}2.056 \mathrm{~g} \\
1 \mathrm{~mL}\end{array}$ & $\begin{array}{l}5.5 \text { min at room } \\
\text { temperature }\end{array}$ & PEMA & $\begin{array}{l}\text { MAOP, } \\
\text { 1,6-HDMA }\end{array}$ & 437 & 094 \\
\hline $\begin{array}{l}\text { Lucitone } \\
550\end{array}$ & $\begin{array}{l}\text { Dentsply Ind. } \\
\text { Com. Ltda, Rio de } \\
\text { Janeiro, RJ, } \\
\text { Brazil }\end{array}$ & $\begin{array}{l}\text { Heat-polymerized } \\
\text { acrylic resin }\end{array}$ & $\begin{array}{l}2.1 \mathrm{~g} \\
1 \mathrm{~mL}\end{array}$ & $\begin{array}{l}\text { Short cycle: } 90 \\
\text { min at } 73^{\circ} \mathrm{C} \text { and } \\
100^{\circ} \mathrm{C} \text { for } 30 \mathrm{~min} \\
\text { Long cycle: } 9 \\
\text { hours at } 71^{\circ} \mathrm{C}\end{array}$ & PMMA & $\begin{array}{l}\text { MMA, } \\
\text { EDGMA }\end{array}$ & 65173 & 64979 \\
\hline
\end{tabular}

PEMA, poly (ethyl methacrylate); PMMA, poly (methyl methacrylate); BMA, butyl methacrylate; IBMA, isobutyl methacrylate; 1,6 - HDMA, (1,6-hexanediol dimethacrylate); MAOP, ß-methacryloyl oxyethyl propionate; MMA, methyl methacrylate; EDGMA, (ethylene glycol dimethacrylate) 
that the manufacturer of Lucitone 550 recommends two different polymerization cycles, two groups $(n=30)$ of denture base resin specimens were prepared and polymerized using either the short ( 90 minutes at $73^{\circ} \mathrm{C}$ and $100^{\circ} \mathrm{C}$ for 30 minutes) or the long cycle ( 9 hours at $71^{\circ} \mathrm{C}$ ). Two test specimens were prepared in the flask simultaneously. Independent mixtures were prepared for each specimen. After polymerization, the flasks were bench cooled at room temperature for 30 minutes and for 15 minutes under running water before the specimens were removed from the flasks. All specimens were finished as described, had the dimensions verified and were stored in water at $37 \pm 1^{\circ} \mathrm{C}$ for 48 \pm 2 hours before testing 8 .

All specimens were divided into 3 groups $(n=10)$. The control group of each material remained as finished. For waterbath group, the specimens were submitted to a postpolymerization treatment in a water-bath at $55^{\circ} \mathrm{C}$. The autopolymerizing reline resin specimens were held at this temperature for 10 minutes, as suggested by the manufacturer of Duraliner II to reduce the residual monomer taste. Lucitone 550 specimens were held at this temperature for 60 minutes, following the recommendation for denture base resins reported by Tsuchiya, et al. ${ }^{24}$ The specimens were then bench cooled to room temperature before testing. Microwaved specimens received post-polymerization treatment by microwave irradiation in a domestic adjustable-wattage microwave oven with a turntable (BMC38ABHNA, Brastemp da Amazonia S.A., Manaus, Brazil) and irradiating with: 550 W/3 min - Lucitone 550; 650 W/4 min - Duraliner II; 550 W/5 min - Kooliner; 500 W/5 min - Tokuso Rebase Fast and 550 W/4 min - Ufi Gel Hard C. Power/time setting for each material were determined in a preliminary study, which evaluated the effect of 9 different power/exposure time combinations on the flexural strength of the materials investigated in this study ${ }^{29}$. The power/time setting, which produced the highest flexural strength value for each material, was used in the present study.

\section{Flexural Strength Test}

All specimens were subjected to flexural strength testing in a servo-hydraulic universal testing machine (MTS 810, MTS Systems Corporation, Eden Prairie, MN, USA) using 3-point loading. A crosshead speed of $5 \mathrm{~mm} / \mathrm{min}$ was used and the distance between the supports was $50 \mathrm{~mm}$. Load was applied until failure and fracture load was recorded in N. Flexural strength (MPa) was calculated using the equation: $\mathrm{FS}=3 \mathrm{WL} / 2 \mathrm{bd}^{2}$, where FS is the flexural strength, $\mathrm{W}$ is the maximum load before fracture $(\mathrm{N})$, $\mathrm{L}$ is the distance between the supports (50 mm), b is the width of the specimen (mm), and dis the thickness of the specimen $(\mathrm{mm})^{8}$.

\section{Microhardness Test}

After flexural strength test, one fragment of each specimen was selected for microhardness test. The hardness of all specimens was obtained using a Vickers diamond indenter. Vickers indentation (VHN) is a valid tool for evaluating the hardness and viscoelastic responses of polymers ${ }^{14}$, and some studies have used the VHN test to evaluate the hardness of denture base acrylic resin ${ }^{17}$ and acrylic resin denture teeth ${ }^{18}$. Measurements of VHN were made with a microhardness indenter machine (Micromet 2100; Buehler, Lake Bluff, IL, USA) at a 25 gf load for 30 seconds. When Duraliner was tested, the load was 10 gf, so that the indentation could be properly measured. The operator of the test machine read the lengths of the diagonals immediately after each indentation, with a minimal (as short as 10 seconds) period of time elapsed between making and reading the indentations. It was assumed that due to the short time elapsed between making and reading the indentation, the viscoelastic recovery of the diagonals after indentation was minimal ${ }^{14}$. The operator measured the diagonals, and the equipment automatically converted these measurements to VHN numbers $\left(\mathrm{kg} / \mathrm{mm}^{2}\right)$ with a scale of 1 digit to the right of the decimal point in a number. Twelve indentations were made on each specimen, and the mean value was calculated.

The influence of the main factors (material and treatment) on the flexural strength and Vickers hardness was analyzed by two-way analysis of variance (ANOVA), followed by Tukey's test $(\alpha=0.05)$.

\section{RESULTS}

Two-way ANOVA for the flexural strength results showed that significant differences were found for the 2 main factors (material and treatment) and their interaction $(\mathrm{p}<0.001)$. Table 2 shows that Lucitone 550 (short cycle) microwaved specimens exhibited significantly higher flexural strength than its respective control group. Water-bath post-polymerization treatment promoted a significant increase in the flexural strength of Kooliner and Lucitone 550 (long cycle). The flexural strength of the reline materials Duraliner II, Ufi Gel Hard C and Tokuso Rebase Fast were not affected by any of the postpolymerization treatments.

When the flexural strength of the materials were compared, Lucitone 550 (short cycle) exhibited significantly higher flexural strength than Ufi Gel Hard C and Lucitone 550 (long cycle) in both control and microwave groups. In these groups, no significant differences were found between the heatpolymerized acrylic resin Lucitone 550 (short cycle) and the autopolymerizing reline resin Tokuso Rebase Fast, which, in turn, was not significantly different from Ufi Gel Hard C and Lucitone 550 (long cycle). Kooliner and Duraliner II specimens produced lower flexural strength than the other materials. No significant difference was found between Kooliner and Duraliner II controls, whereas Kooliner showed significantly higher flexural strength than Duraliner II after both water-bath and microwave post-polymerization treatments. For the specimens submitted to water-bath post-polymerization treatment, there were no significant differences among Lucitone 550 (short and long cycles), Ufi Gel Hard C, and Tokuso Rebase Fast materials. In addition, no significant difference was observed between Kooliner and Lucitone 550 (short cycle).

Two-way ANOVA for Vickers hardness results indicated that significant differences were found only for the factor material $(p<0.001)$. Table 3 presents the hardness means of the materials and the results of Tukey's HSD pos hoc test $(\alpha=0.05)$. Ufi Gel Hard C was significantly harder than the other materials. No significant difference was observed between Lucitone 550 
specimens polymerized using either short or long cycle. Tokuso Rebase Fast material showed lower VHN values than Lucitone 550 and higher than Kooliner and Duraliner II resins, which were not significantly different from each other.

\section{DISCUSSION}

Based on the present methodology, the hypothesis that the flexural strength of autopolymerizing and heat-polymerized acrylic resins could be affected by the post-polymerization treatments was accepted. The results demonstrated that waterbath post-polymerization treatment increased the flexural strength of Kooliner and Lucitone 550 (long cycle). Two mechanisms may explain these results. First, the residual monomer content of specimens submitted to water-bath postpolymerization treatment might have been reduced, in part, by diffusion of the monomer molecules into the water ${ }^{27}$. This diffusion process is known to be enhanced by increasing the water temperature ${ }^{16,24}$. Second, the existence of free radicals in the polymer chains would favor the occurrence of the continuous polymerization phenomenon ${ }^{11}$. These hypotheses are supported by the results of an earlier report ${ }^{25}$, in which immersion in hot water promoted a significant reduction in the residual monomer content for all materials evaluated in the present investigation.

For microwave post-polymerization treatment, the flexural strength of Lucitone 550 specimens (short cycle) was also improved. A plausible explanation for this result is the further polymerization produced by microwave irradiation, thereby reducing the residual monomer content ${ }^{1,5}$. In this study, Lucitone 550 material was polymerized according to the manufacturer's instructions, which included a terminal boil for 30 minutes. Previous studies have shown that heat-polymerized acrylic resins should be maintained for at least 1 hour in terminal boiling to achieve the maximum monomer conversion ${ }^{6,28}$. Probably, the short boiling time adopted in this study resulted in lower degree of conversion, which might have been improved after microwave post-polymerization treatments. The favorable effect of microwave post-polymerization treatment was also observed in the studies by Yunus, et al. ${ }^{30}$ and Polyzois, et al. ${ }^{19}$, who reported that the strength of specimens of denture base resins repaired with autopolymerizing acrylic resins was improved by effective microwave irradiation. Similarly, Blagojevic and Murphy ${ }^{5}$ showed that microwaving of a polymerized autopolymerizing reline resin for 3 minutes at 600 $\mathrm{W}$ improved its mechanical properties and reduced residual monomer by almost a factor of four.

The flexural strength of Ufi Gel Hard C, Tokuso Rebase Fast and Duraliner II was not significantly improved by any of the post-polymerization treatments. The results obtained for Tokuso Rebase Fast and Ufi Gel Hard could be attributed to their composition. Tokuso Rebase Fast and Ufi Gel Hard C are composed of poly (ethylmethacrylate) and their liquid contains a cross-linking agent, 1,6-hexanediol dimethacrylate (1,6HDMA $)^{2,3}$. The long distance between the 2 methacrylate groups of 1,6-hexanediol dimethacrylate results in more reactivity of the second methacrylate group ${ }^{22,29}$. Therefore, a high degree of conversion of dimethacrylates contained in Ufi Gel Hard C and Tokuso Rebase Fast may occur by the chemical activation reaction, thereby resulting in a highly cross-linked polymer. For Duraliner II, one factor that may have influenced its behavior is the lowest powder/liquid ratio ${ }^{10}$. According to Lamb $^{12}$, with the lower powder/liquid ratio, the ratio of peroxide/ amine will be lowered and hence the rate of decomposition of the peroxide increased. Consequently, the net effect will be a

TABLE 3- VHN means $\left(\mathrm{kg} / \mathrm{mm}^{2}\right)$ ( \pm standard deviation)

\begin{tabular}{ll} 
Material & Vickers Hardn \\
\hline Ufi Gel Hard C & $17.4( \pm 0.67)$ A \\
Lucitone 550 (short cycle) & $15.2( \pm 1.26)$ B \\
Lucitone 550 (long cycle) & $14.1( \pm 0.44)$ B \\
Tokuso Rebase Fast & $6.5( \pm 0.66)$ C \\
Duraliner II & $2.6( \pm 0.26)$ D \\
Kooliner & $2.6( \pm 0.50)$ D
\end{tabular}

The same uppercase letter in a column represents values that were not significantly different at $p=0.05$.

TABLE 2- Flexural strength means (MPa) ( \pm standard deviation)

\begin{tabular}{llll} 
Material & $\begin{array}{l}\text { Groups } \\
\text { Control }\end{array}$ & Water-bath & Microwave \\
\hline & & & \\
Lucitone 550 (short cycle) & $57.50( \pm 5.35) \mathrm{A}^{\mathrm{a}}$ & $51.26( \pm 6.16) \mathrm{A}^{\mathrm{ab}}$ & $67.40( \pm 4.79) \mathrm{B}^{\mathrm{a}}$ \\
Tokuso Rebase Fast & $55.22( \pm 4.17) \mathrm{A}^{\mathrm{ab}}$ & $57.45( \pm 5.81) \mathrm{A}^{\mathrm{a}}$ & $62.81( \pm 4.03) \mathrm{A}^{\mathrm{ab}}$ \\
Ufi Gel Hard C & $53.20( \pm 9.30) \mathrm{A}^{\mathrm{b}}$ & $57.23( \pm 11.59) \mathrm{A}^{\mathrm{a}}$ & $58.15( \pm 6.62) \mathrm{A}^{\mathrm{b}}$ \\
Lucitone 550 (long cycle) & $50.81( \pm 7.70) \mathrm{A}^{\mathrm{b}}$ & $58.82( \pm 9.20) \mathrm{B}^{\mathrm{a}}$ & $55.13( \pm 5.05) A \mathrm{~B}^{\mathrm{b}}$ \\
Kooliner & $32.52( \pm 1.93) \mathrm{A}^{\mathrm{c}}$ & $46.17( \pm 2.03) \mathrm{B}^{\mathrm{b}}$ & $36.51( \pm 2.18) \mathrm{A}^{\mathrm{c}}$ \\
Duraliner II & $26.16( \pm 1.01) \mathrm{A}^{\mathrm{c}}$ & $26.35( \pm 1.14) \mathrm{A}^{\mathrm{c}}$ & $25.30( \pm 2.10) \mathrm{A}^{\mathrm{d}}$
\end{tabular}

Within each line, entries with the same uppercase letter were not significantly different $(p=0.05)$. The same superscript letter in a column represents values that were not significantly different at $p=0.05$. 
decrease in the concentration of longer-lived radicals, which are essential for the post-polymerization reaction.

Comparing the control groups, Lucitone 550 specimens processed using long cycle polymerization, which did not include a period at $100^{\circ} \mathrm{C}$, produced specimens with the lower flexural strength values than Lucitone 550 specimens using short cycle. These results may be attributed to the variation of time and temperature during polymerization, which can influence the amount of residual monomer content in the polymerized acrylic resin ${ }^{6,28}$. A previous study ${ }^{25}$ has demonstrated that the terminal boiling $\left(100^{\circ} \mathrm{C}\right)$ period included in the short polymerization cycle produced specimens with lower level of residual monomer than those polymerized by the long cycle. This may explain the higher flexural strength of the specimens of Lucitone 550, polymerized using the short cycle ${ }^{9}$. Favorably, the flexural strength values of the autopolymerizing reline resin Tokuso Rebase Fast were not significantly different from that of the heat-polymerized acrylic resin Lucitone 550 (long cycle and short cycle). Likewise, Ufi Gel Hard C did not differ from Lucitone 550 polymerized using the long cycle. These findings are probably related to the fact that these reline materials are both highly cross-linked polymers ${ }^{3}$ and support the observations from clinical trials in which Tokuso Rebase Fast demonstrated excellent clinical performance after 12-month observation $^{7,15}$. On the other hand, Kooliner and Duraliner II displayed the lowest flexural strength means. Although Duraliner II is also a cross-linked material, it produced a low flexural strength mean. As previously stated, the low powder/ liquid ratio used for Duraliner II may have accounted for this result. From the clinical standpoint, the results indicated that Kooliner and Duraliner II should be accepted as temporary materials due to the limited mechanical properties presented. However, as the flexural strength obtained with Kooliner was comparable to that of Lucitone 550 (short cycle) after waterbath post-polymerization treatment, this procedure could be used to improve the longevity of the denture bases relined with this material.

The hypothesis that the Vickers hardness of autopolymerizing and heat-polymerized acrylic resins tested would be influenced by post-polymerization treatments was rejected. Similar finding was found by Blagojevic and Murphy ${ }^{5}$, who demonstrated that autopolymerizing acrylic resin had no difference in hardness values before and after microwaving at $600 \mathrm{~W}$ for 3 minutes. These results, taken together with those from flexural tests, suggest that the effect of the postpolymerization treatments was more pronounced in the bulk of the specimens rather than in their superficial layer. This theory is supported by other study ${ }^{16}$, in which higher hardness values were recorded at greater specimen depths after an additional cycle of polymerization using either microwave energy or hot water. The absence of any detectable effect of water-bath and microwave irradiation treatments on the superficial layer of the tested materials may also be explained by the presence of oxygen, which may have competed for free radicals during the post-polymerization treatment. The reactivity of oxygen with free radicals has been reported to be higher than that of free radicals with monomers ${ }^{13}$.

Although Tokuso Rebase Fast and Ufi Gel Hard C contain the same cross-linking agent in the liquid, it was interesting to note that the former showed significantly lower hardness values. This may be explained by the use of the monofunctional monomer, 39.8\% ß-methacryloyl oxyethyl propionate (MAOP) that constitutes the liquid component of Tokuso Rebase Fast material. The MAOP molecule contains 2 esteric bonds that form flexible polymer chains upon polymerization ${ }^{3}$. The flexibility of the polymer chain may account for the relatively lower hardness of Tokuso Rebase Fast in comparison to Ufi Gel Hard C. It could be also hypothesized that the greater surface hardness of Ufi Gel Hard C was due to the inclusion of inorganic filler particles and the highly cross-linked polymer structure. To the best of the authors' knowledge, no other studies have evaluated extensively this new material since its introduction to the market. Studies investigating Ufi Gel Hard C composition must be gathered to validate the current hypothesis. As expected, Lucitone 550 specimens polymerized by short and long cycles were significantly harder than those made with Tokuso Rebase Fast, Kooliner and Duraliner II. Finally, it was not surprising that Kooliner and Duraliner II showed the lowest Vickers hardness values of all materials. According to Rawls ${ }^{20}$, the butyl/isobutyl methacrylate molecules increase the backbone separation of the polymer molecules, decreasing the intermolecular interaction. Thus, the isobutyl (Kooliner) possesses a lower surface hardness, and the n-butyl (Duraliner II) has an even lower hardness. The lowest hardness values observed for Duraliner II could also be related to its low powder/ liquid ratio, which will result in a high residual monomer left in the polymerized resin ${ }^{10,25}$.

Based upon the limitations imposed in the present study, these findings suggest that post-polymerization treatments offer advantages on the flexural strength of some tested materials. However, the interpretation of the results from this report must be made with caution and further investigations are required in order to clarify any clinical influence of the water-bath and microwave post-polymerization treatments on the longevity of intact and relined denture bases.

\section{CONCLUSIONS}

Under the experimental conditions used in this study the following conclusions can be drawn:

1. The flexural strength of the heat-polymerized resin Lucitone 550 (short cycle) was increased after microwave postpolymerization treatment.

2. After water bath post-polymerization treatment, the heatpolymerized resin Lucitone 550 (long cycle) and autopolymerizing resin Kooliner showed an increase in flexural strength values.

3. Duraliner II and Kooliner showed the lowest flexural strength among the relining materials. The autopolymerizing resins Tokuso Rebase Fast and Ufi Gel Hard C exhibited flexural strength comparable to that of the conventional heatpolymerized Lucitone 550, regardless of the polymerization cycle.

4. No significant effect of post-polymerization treatments 
was observed on the Vickers hardness.

5. Ufi Gel Hard C demonstrated significantly higher Vickers hardness compared to the other tested materials. Vickers hardness of Lucitone 550 was significantly higher than that of Tokuso Rebase Fast, Duraliner II and Kooliner.

\section{ACKNOWLEDGMENTS}

This study was supported by The State of São Paulo Research Foundation (FAPESP; Grant 01/01403-4). The authors thank the manufacturers for providing all the materials evaluated in this study.

\section{REFERENCES}

1- Araújo PHH, Sayer C, Poço JGR, Giudici R. Technique for reducing residual monomer content in polymers. a review. Polym Eng Sci. 2002;42:1442-68

2- Archadian N, Kawano F, Ohguri T, Ichikawa T, Matsumoto N. Flexural strength of rebased denture polymers. J Oral Rehabil. 2000;27:690-6.

3- Arima T, Murata H, Hamada T. Properties of highly cross-linked autopolymerizing reline acrylic resin. J Prosthet Dent. 1995;73:55-9.

4- Barclay SC, Forsyth A, Felix DH, Watson IB. Case report hypersensitivity to denture materials. Br Dent J. 1999;187:350-2.

5- Blagojevic V, Murphy VM. Microwave polymerization of denture base materials. A comparative study. J Oral Rehabil. 1999;26:804-8.

6- Harrison A, Huggett R. Effect of the curing cycle on residual monomer levels of acrylic resin denture base polymers. J Dent. 1992;20:370-4.

7- Haywood J, Basker RM, Watson CJ, Wood DJ. A comparison of three hard chairside denture reline materials. Part I. Clinical evaluation. Eur J Prosthodont Rest Dent. 2003;11:157-63.

8- International Standards Organization. ISO 1567 for denture base polymers. Geneva: ISO, 1998. ISO Store at http://www.iso.ch/iso/en/ prods-services/ISOstore/store.html.

9- Jerolimov V, Jagger RG, Milward PJ. Effect of the curing cycle on acrylic denture base glass transition temperatures. J Dent. 1991;19:2458.

10 - Kedjarune U, Charoenworaluk N, Koontongkaew S. Release of methyl methacrylate from heat-cured and autopolymerized resins: cytotoxicity testing related to residual monomer. Aust Dent J. 1999;44:25-30.

11- Lamb DJ, Ellis B, Priestley D. Loss into water of residual monomer from autopolymerizing dental acrylic resin. Biomaterials. 1982;3:1559.

12- Lamb DJ, Ellis B, Priestley D. The effects of process variables on levels of residual monomer in autopolymerizing dental acrylic resin. J Dent. 1983;11:80-8

13- Lee S, Lai Y, Hsu T. Influence of polymerization conditions on monomer elution and microhardness of autopolymerized polymethyl methacrylate resin. Eur J Oral Sci. 2002;110:179-83.

14- Low IM. Effects of load and time on the hardness of a viscoelastic polymer. Mater Res Bull. 1998;33:1753-8.
15- Matsumura H, Tanoue N, Kawasaki K, Atsuta M. Clinical evaluation of a chemically cured hard denture relining material. J Oral Rehabil. 2001;28:640-4.

16- Mello JAN, Braun KO, Rached RN, Del Bel Cury AA. Reducing the negative effects of chemical polishing in acrylic resins by use of an additional cycle of polymerization. J Prosthet Dent. 2003;89:598-602.

17- Neppelenbroek KH, Pavarina AC, Vergani CE, Giampaolo ET. Hardness of heat-polymerized acrylic resins after disinfection and longterm water immersion. J Prosthet Dent. 2005;93:171-6.

18- Pavarina AC, Vergani CE, Machado AL, Giampaolo ET, Teraoka MT. The effect of disinfectant solutions on the hardness of acrylic resin denture teeth. J Oral Rehabil. 2003;30:749-52.

19- Polyzois GL, Tarantili PA, Frangou MJ, Andreopoulos AG. Fracture force, deflection at fracture, and toughness of repaired denture resin subjected to microwave polymerization or reinforced with wire or glass fiber. J Prosthet Dent. 2001;86:613-9.

20 - Rawls HR. Dental Polymers. In: Anusavice KJ, W. B. Saunder Company. Phillips' Science of Dental Materials, St Louis; 2003. p.14369.

21 - Reis JMSN, Vergani CE, Pavarina AC, Giampaolo ET. Effect of relining, water storage and cyclic loading on the flexural strength of a denture base acrylic resin. J Dent. 2006;34:420-6.

22- Ruyter IE, Øysaed H: Conversion in denture polymer. J Biomed Mater Res. 1982;16:741-54.

23- Takahashi Y, Kawaguchi M, Chai J. Flexural strength at the proportional limit of a denture base material relined with four different denture reline material. Int J Prosthodont 1997;10:508-12.

24- Tsuchiya H, Hoshino Y, Tajima K, Takagi N. Leaching and cytotoxicity of formaldehyde and methyl metacrylate from acrylic resin denture base materials. J Prosthet Dent. 1994;71:618-24.

25- Urban VM, Machado AL, Oliveira RV, Vergani CE, Pavarina AC, Cass, QB. Residual monomer of reline acrylic resins Effect of water-bath and microwave post-polymerization treatments. Dent Mat. 2007; 23:363-8.

26- Vallittu PK. The effect of surface treatment of denture acrylic resin on the residual monomer content and its release into water. Acta Odontol Scand. 1996;54:188-92.

27- Vallittu PK, Miettinen V, Alakuijala P. Residual monomer content and its release into water from denture base materials. Dent Mater. 1995;11:338-42.

28- Vallittu PK, Ruyter IE, Buykuilmaz S. Effect of polymerization temperature and time on the residual monomer content of denture base polymers. Eur J Oral Sci. 1998;106:588-93.

29- Vergani CE, Seo RS, Pavarina AC, Reis JMN. Flexural strength of autopolymerizing denture reline resins with microwave postpolymerization treatment. J Prosthet Dent. 2005;93:577-83.

30- Yunus N, Harrison A, Huggett R. Effect of microwave irradiation on the flexural strength and residual monomer levels of an acrylic resin repair material. J Oral Rehabil. 1994;21:641-8. 